\title{
The Effect of Multi-Years Reclaimed Water Irrigation on Dryland Carbon Sequestration in the North China Plain
}

\author{
Yanbing Chi, Qiang Zheng, Peiling Yang *, Shumei Ren and Ning Ma \\ College of Water Resources and Civil Engineering, China Agricultural University, Beijing 100083, China; \\ chiice@163.com (Y.C.); zhengqiang@163.com (Q.Z.); renshumei@163.com (S.R.); maning@163.com (N.M.) \\ * Correspondence: yangpeiling@126.com; Tel./Fax: +86-10-6273-7866
}

Citation: Chi, Y.; Zheng, Q.; Yang, P.; Ren, S.; Ma, N. The Effect of Multi-Years Reclaimed Water Irrigation on Dryland Carbon Sequestration in the North China Plain. Water 2021, 13, 3260. https:// doi.org/10.3390/w13223260

Academic Editors: Layla Ben Ayed, Eleni Golomazou, Panagiotis Karanis, Patrick Scheid, Ourania Tzoraki, Anna Lass and Muhammad Shahid Iqbal

Received: 13 October 2021 Accepted: 15 November 2021 Published: 17 November 2021

Publisher's Note: MDPI stays neutral with regard to jurisdictional claims in published maps and institutional affiliations.

Copyright: (c) 2021 by the authors. Licensee MDPI, Basel, Switzerland. This article is an open access article distributed under the terms and conditions of the Creative Commons Attribution (CC BY) license (https:/ / creativecommons.org/licenses/by/ $4.0 /)$.

\begin{abstract}
Reclaimed water is an alternative water source which could alleviate the shortage of water resources in agricultural systems. Many researchers have studied the effect of reclaimed water on soil environment, crop yield, etc. However, carbon sequestration in reclaimed water irrigated agricultural systems is less studied. This study investigates methane uptake and photosynthesis in reclaimed water irrigation systems contributing to carbon sequestration estimation and analyzes the important factors impacting them. The results show that $\mathrm{CH}_{4}$ uptake is related to soil water-filled pore space (WFPS) with a quadratic and it has the highest uptake when WFPS is between 40 and $50 \%$. Long-term reclaimed water irrigation could significantly decrease $(p<0.05) \mathrm{CH}_{4}$ uptake and macroaggregate stability in the topsoil. However, reclaimed water had no significant impact on photosynthesis in comparison. The type of fertilizer is an important factor which impacts $\mathrm{CH}_{4}$ emission from soil; urea had a lower $\mathrm{CH}_{4}$ uptake and a higher $\mathrm{CO}_{2}$ emission than slow-released fertilizer. Overall, reclaimed water irrigation could effectively decrease soil carbon sequestration. A soil wetted proportion level of $40-50 \%$ was recommended in this study for favorable methane oxidation. Slow-released fertilizer in reclaimed water irrigated agriculture could better control soil carbon emission and soil carbon absorption.
\end{abstract}

Keywords: $\mathrm{CH}_{4}$ uptake; photosynthesis; carbon exchange; soil environment; water-filled pore space; types of fertilizer

\section{Introduction}

Agricultural $\mathrm{CH}_{4}$ production from soil plays an important role in global radiation and the greenhouse effect. Some studies showed that $\mathrm{CH}_{4}$ contributes $18 \%$ of global radiation [1,2], and its greenhouse effect capacity is 26 times that of $\mathrm{CO}_{2}$ [2]. Lashof et al. [3] and Jain et al. [4] considered that global $\mathrm{CH}_{4}$ emissions were rising. Dryland carbon sequestration is necessary for global carbon balance, which includes $\mathrm{CH}_{4}$ uptake and photosynthesis. Most studies showed that dryland $\mathrm{CH}_{4}$ uptake accounts for $6 \%$ of the total global methane consumption, and it is a very important part of $\mathrm{CH}_{4} \operatorname{sink}[5,6]$. The soil carbon sequestration could be impacted by many factors, such as temperature, soil water content, fertilizer, soil environment, etc. Temperature can significantly promote the activity of methane oxidizing bacteria and increase methane production [7]. Soil moisture can control bacteria activity and affect the soil oxygen content. Previous literature also studied the relationship between $\mathrm{CH}_{4}$ oxidation capacity and soil moisture, showing that it increases with the increase in soil moisture [8]. Previous studies also demonstrated that there is a strong relationship between methane production and soil oxygen concentration [9]. Methane oxidizing bacteria could have a strong relationship with soil EC, nitrogen [10]. These driving factors can be divided into two types: (1) Dynamic type, water change and temperature could drive $\mathrm{CH}_{4}$ emission and significantly impact crop growth. (2) Biochemistry type, that attributed soil properties could participate in $\mathrm{CH}_{4}$ production processes and crop growth by impacting the soil microorganism and the soil electronic change. 
In recent years, with the development of intensive agricultural systems, the water resources in some regions are vulnerable [11]. Reclaimed water as an alternative water source has gradually been used in agricultural irrigation. Most studiesshowed that longterm reclaimed water irrigation could effectively impact the soil $\mathrm{pH}, \mathrm{EC}$, and soil organic carbon $[12,13]$ and could effectively impact crop growth and photosynthesis $[14,15]$. Moreover, some researchers showed that sewage water could increase soil $\mathrm{CH}_{4}$ emission in the paddy field agricultural system [16,17]. These studies suggest that the increasing gas emissions from soil could contribute to the microorganism activity [18] or the changing soil environment [19] impacted by reclaimed water. However, few studies have explored the reason for this. Therefore, it is necessary to determine the effect of reclaimed water on soil $\mathrm{CH}_{4}$ emission and observe the patterns of soil carbon sinks under reclaimed water irrigated agricultural systems. This effectively guided the reclaimed water irrigation and balanced carbon emission.

The present study focused on the effect of reclaimed water on the patterns of main carbon sequestration (dryland $\mathrm{CH}_{4}$ uptake, crop photosynthesis) under two types of fertilizer (urea and slow-released fertilizer) and illustrated the factors affecting these changes under reclaimed water irrigation. Our findings could effectively guide the reclaimed water irrigation technology contributing to carbon balance in the soil-atmosphere system, and are beneficial to fertilizer in reclaimed water irrigated agriculture.

\section{Materials and Methods}

\subsection{Experiment Design}

The experiment site of Tongzhou, Beijing, China, is shown in Figure 1. The details of trail conditions and agricultural management are described in Chi et al. [20]. The experiment set two types of water quality (reclaimed water and underground water) and two types of fertilizer (urea and slow released fertilizer), as shown in Table 1. The properties of the soil in all treatments were measured at the beginning of the experiment. The sampling took place in October 2013 and the details are shown in Table 2.

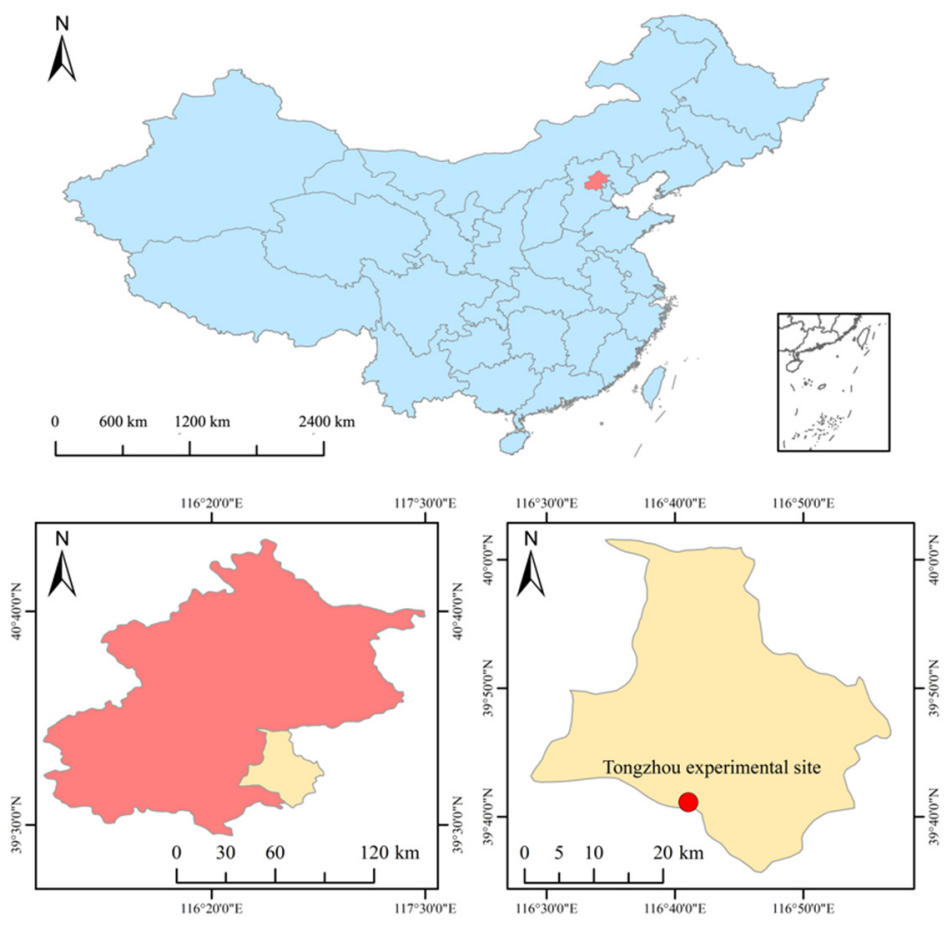

Figure 1. Location of experimental site. 
Table 1. The number of experiment.

\begin{tabular}{ccccc}
\hline Item & Water Quality & Fertilizer & Number & Remarks \\
\hline 1 & underground water/CW & urea/UF & CUF & control group \\
2 & underground water/CW & slow released fertilizer/AF & CAF & experimental \\
3 & reclaimed water/RW & urea/UF & RUF & group \\
4 & reclaimed water/RW & slow released fertilizer/AF & RAF & . \\
\hline
\end{tabular}

Table 2. The soil background value at beginning of planting.

\begin{tabular}{lccccccc}
\hline \multicolumn{2}{c}{ Item } & $\begin{array}{c}\mathrm{NO}_{3} \\
(\mathbf{m g} / \mathbf{k})\end{array}$ & $\begin{array}{c}\mathbf{N H}_{\mathbf{4}}{ }^{+} \\
\mathbf{( m g / k g})\end{array}$ & $\mathbf{p H}$ & $\begin{array}{c}\text { EC } \\
(\mathbf{u s} / \mathbf{c m})\end{array}$ & $\begin{array}{c}\text { TN } \\
(\mathbf{m g} / \mathbf{k g})\end{array}$ & $\begin{array}{c}\text { SOC } \\
(\mathbf{m g} / \mathbf{k g})\end{array}$ \\
\hline RUF & 2013 & $8.21 \pm 2.12$ & $8.94 \pm 2.12$ & $7.81 \pm 0.32$ & $531.23 \pm 12$ & $3.12 \pm 0.22$ & $11.06 \pm 0.13$ \\
CUF & 2013 & $8.10 \pm 1.94$ & $8.73 \pm 2.34$ & $7.93 \pm 0.11$ & $654.51 \pm 34$ & $3.01 \pm 0.22$ & $8.01 \pm 0.77$ \\
RAF & 2013 & $8.11 \pm 0.14$ & $8.19 \pm 3.42$ & $8.01 \pm 0.15$ & $431.43 \pm 24$ & $2.94 \pm 0.13$ & $10.34 \pm 0.54$ \\
CAF & 2013 & $8.13 \pm 2.34$ & $8.41 \pm 2.32$ & $8.04 \pm 0.24$ & $351.71 \pm 15$ & $2.01 \pm 0.14$ & $11.23 \pm 0.54$ \\
\hline
\end{tabular}

\subsection{The Sampling Method and Collection}

Soil $\mathrm{CH}_{4}$ emission: The $\mathrm{CH}_{4}$ emission from the soil was measured by chamber-gas chromatography, using Agilent GC-6820 (Agilent Technologies Inc., Santa Clara, CA, USA), $20 \mathrm{~mL}$ of gas was collected in each sample. The square chamber was $50 \mathrm{~cm} \times 50 \mathrm{~cm} \times 50 \mathrm{~cm}$, and it was inserted to a depth of $5 \mathrm{~cm}$ in the soil. One chamber and stopwatch was inserted into each plot, 2-3 people sampled at the same time, and a gas collection was fulfilled in $10 \mathrm{~s}$. Samples were taken between 14:00 p.m. and 16:00 p.m. in wheat growth season and between 9:00 a.m. and 11:00 a.m. in maize growth season [21]. Every treatment had three replicates. The calculation of $\mathrm{CH}_{4}$ emission was described by Hashimoto et al. [22] and Konda et al. [23]. The soil average temperature of $0-20 \mathrm{~cm}$ was recorded when the gas was collected.

Crop photosynthesis: The rate of crop photosynthesis was measured by a portable photosynthetic gas analysis system (CI-340, CID, America), every treatment had 5 replicates. During the winter wheat period, the photosynthesis of flag leaf was measured. The sample was collected on early jointing, mid jointing, botting, heading, and filling stage. During the summer maize period, the collecting time was V3 (third leaf), V6 (sixth leaf), V12 (twelfth leaf), VT (tasseling), R2 (blister stage) and R3 (milk stage).

Carbon balance means to the carbon gas exchange. The calculation is as follows:

$$
\text { Carbon balance }=\mathrm{C}_{4}+\mathrm{C}_{\mathrm{p}}-\mathrm{C}_{2}
$$

$\mathrm{C}_{2}$ was cumulative $\mathrm{CO}_{2}$ emission (t.hm ${ }^{-2}$ ); $\mathrm{C}_{\mathrm{p}}$ was et photosynthesis in wheat-summer rotation system (t.hm $\left.{ }^{-2}\right) ; \mathrm{C}_{4}$ was cumulative $\mathrm{CH}_{4}$ emission $\left(\mathrm{t} . \mathrm{hm}^{-2}\right)\left(\mathrm{hm}^{2}=1000 \times \mathrm{m}^{2}\right)$, the value converted to $\mathrm{CO}_{2}$-eq from soils during one crop production in wheat-summer rotation system.

WFPS and temperature: soil water content and temperature were measured by soil moisture and temperature sensors (ET-100, Insentek, China), the buried depth of sensor was $1 \mathrm{~m}$. The WFPS in $20 \mathrm{~cm}$ depth soil was as follows:

$$
\mathrm{WFPS}=\frac{\theta_{\mathrm{v}}}{1-\mathrm{r} / \rho}
$$

$\theta_{\mathrm{v}}$ was the soil water content; $\mathrm{r}$ was the soil bulk density; $\rho$ was the soil density $2.65 \mathrm{~g} / \mathrm{cm}^{2}$.

$\mathrm{pH}, \mathrm{EC}$ and soil nitrogen: Soil samples were collected when the photosynthesis was measured, every treatment had five replicates and the depth was $0-30 \mathrm{~cm}$. The $\mathrm{pH}$ and EC was measured by a multi-parameter tester (SG23, Mettler Toledo, Shanghai, China) and the soil nitrogen $\left(\mathrm{NH}_{4}{ }^{+}, \mathrm{NO}_{3}{ }^{-}\right)$was measured by a continuous flowing analyzer (Alliance FUTURA, AMS, Frépillon, France). The measurement method of soil properties referred to 
can be found in [24]. Soil particle size was measured by a laser particle sizer (0.01-3500 um, Mastersizer 3000, Malvern, England).

\subsection{Data Analysis}

All statistical analyses were carried out using SPSS V26 for MacOS (SPSS Inc., Chicago, IL, USA). Analysis of variance (ANOVA) was used to determine treatment effects. The least significant difference procedure (LSD) and contrasts with a probability level of 0.05 were used to determine significant differences between treatment means by using a t-test. In this study, average refers to the arithmetic mean. Correlations were assessed by Pearson's correlation coefficient $(\alpha)$. The soil carbon exchange in this paper refers to the carbon content exchanged between soil and atmosphere during the main planting period in winter wheat and summer maize rotation.

\section{Results}

\subsection{Principal Component Analysis}

The PC1 was $55.1 \%$ and the PC2 was $24.9 \%$. As shown in Figure 2, UF treatments in PC2 were higher than AF treatments, and RW (reclaimed water) treatments in PC1 were higher than $\mathrm{CW}$ (clean/underground water) treatments. Type of fertilizer respect PC2, type of water respect PC1. EC, $\mathrm{NO}_{3}{ }^{-}, \mathrm{N}_{2} \mathrm{O}$ and $\mathrm{NH}_{4}{ }^{+}$occurred on the first quadrant. $\mathrm{pH}$, SOC and $\mathrm{CO}_{2}$ occurred on the fourth quadrant. $\mathrm{CH}_{4}$ was at the second quadrant. The $\mathrm{N}_{2} \mathrm{O}$ emission flux was related to $\mathrm{EC}, \mathrm{NO}_{3}{ }^{-}, \mathrm{NH}_{4}{ }^{+}$and $\mathrm{TN}$, the $\mathrm{CO}_{2}$ emission flux was related to $\mathrm{SOC}, \mathrm{pH}$ and $\mathrm{TN}$, but these soil properties had no relationship with soil $\mathrm{CH} 4$ emission. Moreover, all treatments were divided into two parts according to fertilizer type (Figure 2). During the four-year experiment, reclaimed water could effectively soil $\mathrm{pH}, \mathrm{TN}, \mathrm{NO}_{3}{ }^{-}$, and the greenhouse gas $\left(\mathrm{CO}_{2}, \mathrm{~N}_{2} \mathrm{O}\right.$ and $\left.\mathrm{CH}_{4}\right)$ was related to the type quality of irrigated water. The absolute value of $\mathrm{NH}_{4}{ }^{+}, \mathrm{EC}$ and SOC in PC2 was higher than PC1.
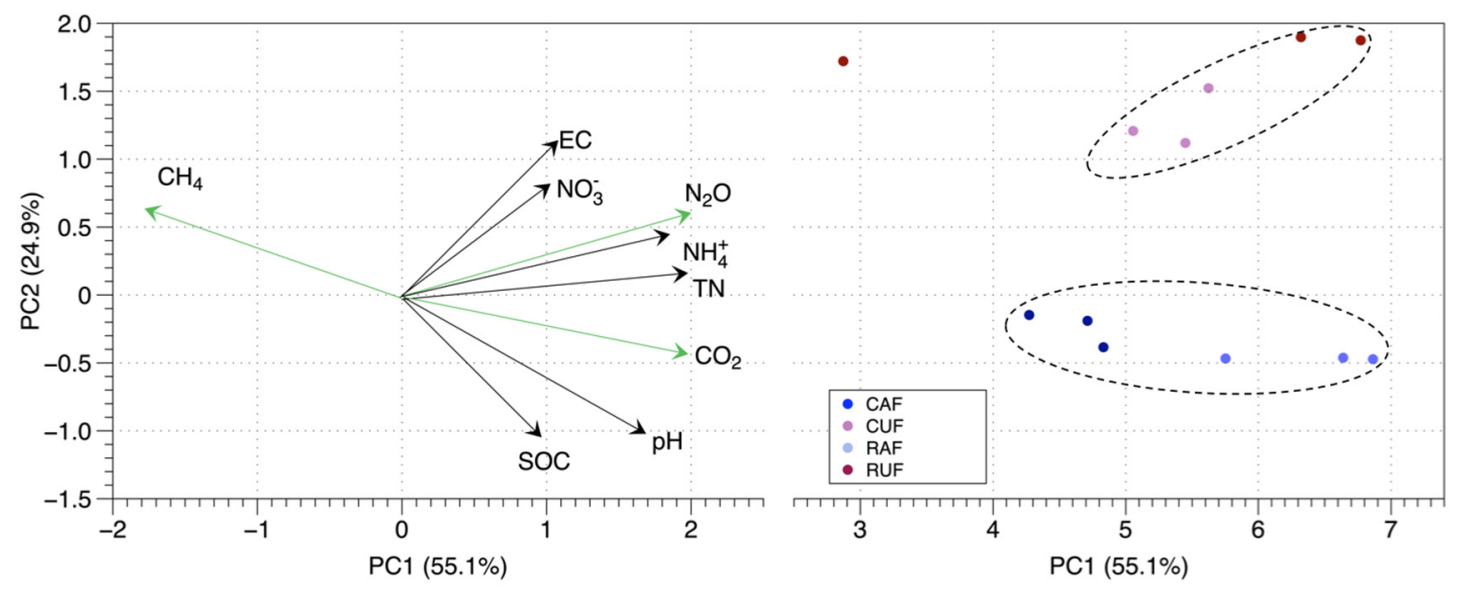

Figure 2. The patterns of soil temperature and WFPS from 2014 to 2015.

\subsection{Soil $\mathrm{CH}_{4}$ Emission}

As shown in Figure 3, soil could absorb methane effectively from 2013 to 2014, and the patterns of methane emission flux were similar in all treatments. As shown in Table 3, reclaimed water could significantly decrease methane uptake between 11.76 and $27.27 \%$, AF could increase the methane uptake in comparison with UF. The order of methane cumulative uptake was RUF $<\mathrm{RAF}<\mathrm{CUF}<\mathrm{CAF}$. 


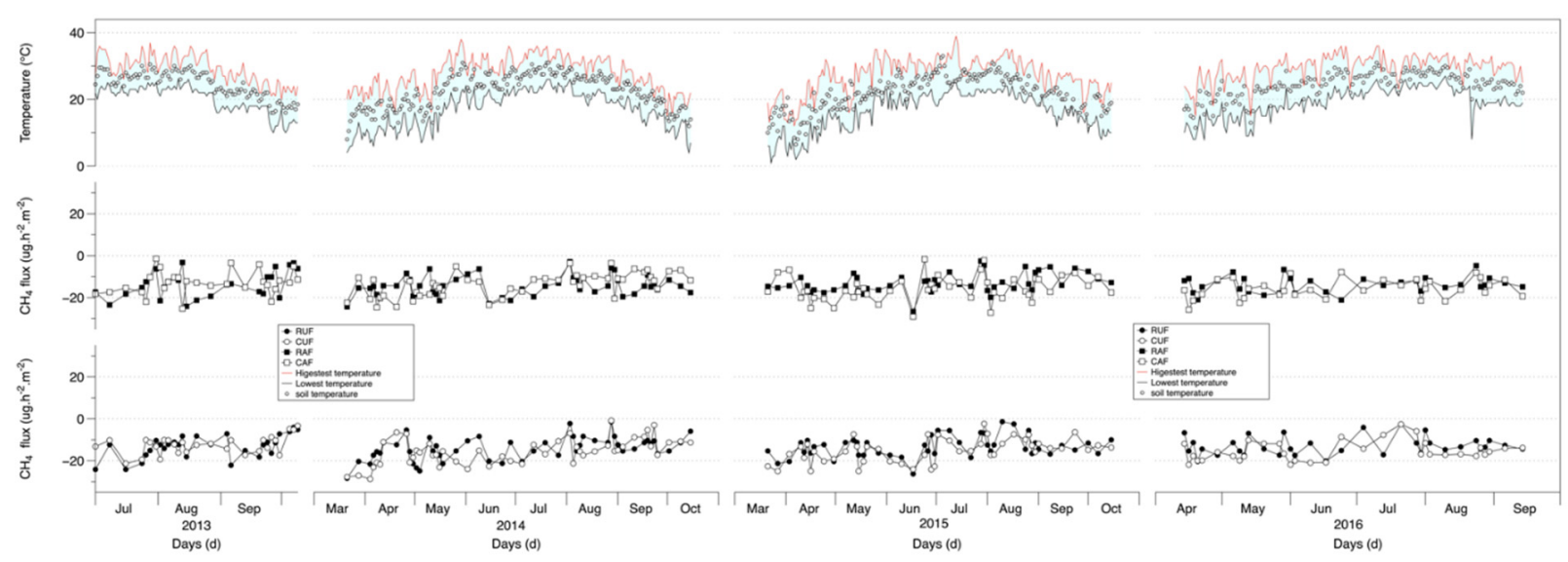

Figure 3. The patterns of temperature and soil $\mathrm{CH}_{4}$ emission flux from 2013 to 2016.

Table 3. The average and cumulative $\mathrm{CH}_{4}$ emission from 2013 to 2016.

\begin{tabular}{ccccccccc}
\hline \multirow{2}{*}{ Treatment } & \multicolumn{2}{c}{2013} & \multicolumn{2}{c}{2014} & \multicolumn{2}{c}{2015} & \multicolumn{2}{c}{2016} \\
\cline { 2 - 9 } & Aver & Cum & Aver & Cum & Aver & Cum & Aver & Cum \\
\hline RUF & $-13.21 \mathrm{a}$ & $-0.079 \mathrm{a}$ & $-13.79 \mathrm{a}$ & $-0.17 \mathrm{a}$ & $-13.25 \mathrm{a}$ & $-0.16 \mathrm{a}$ & $-12.87 \mathrm{a}$ & $-0.11 \mathrm{a}$ \\
CUF & $-12.47 \mathrm{a}$ & $-0.074 \mathrm{a}$ & $-15.26 \mathrm{~b}$ & $-0.19 \mathrm{~b}$ & $-15.04 \mathrm{~b}$ & $-0.18 \mathrm{~b}$ & $-14.86 \mathrm{~b}$ & $-0.14 \mathrm{~b}$ \\
RAF & $-13.53 \mathrm{a}$ & $-0.081 \mathrm{a}$ & $-13.08 \mathrm{a}$ & $-0.16 \mathrm{a}$ & $-13.63 \mathrm{a}$ & $-0.17 \mathrm{a}$ & $-13.45 \mathrm{a}$ & $-0.12 \mathrm{a}$ \\
CAF & $-12.93 \mathrm{a}$ & $-0.077 \mathrm{a}$ & $-13.14 \mathrm{a}$ & $-0.17 \mathrm{a}$ & $-15.58 \mathrm{~b}$ & $-0.19 \mathrm{~b}$ & $-15.12 \mathrm{~b}$ & $-0.14 \mathrm{~b}$ \\
\hline
\end{tabular}

Aver means the average $\mathrm{CH}_{4}$ emission flux during the growth period, unit is ug.h $\mathrm{h}^{-1} \cdot \mathrm{m}^{-2}$.; Cum means the cumulative $\mathrm{CH}_{4}$ emission flux during the growth period, unit is t.hm ${ }^{-2}$. a.b indicate that the significant analysis between different water quality types within the same fertilizer. Means followed by the same letter are not significantly different according to t-test $(p<0.05)$.

In order to analyze the factors that could impact methane emission, the paper shows the relationship between methane and WFPS, soil nitrogen. As shown in Figure 4, the relationship between WFPS and methane was quadratic, and the $\mathrm{R}^{2}$ in AF treatment was higher UF. Meanwhile, the RAF (0.15) and RUF (0.34) was higher CUF (0.13) and CAF (0.26). As shown in Figure 4, there was a strong linear relationship between methane and soil $\mathrm{NH}_{4}{ }^{+}$, the $\mathrm{R}^{2}$ in RUF and CUF was 0.65 and 0.32 , respectively (Table 4). However, there is no relationship between methane and soil $\mathrm{NO}_{3}{ }^{-}$.

Table 4. The regression between $\mathrm{CH}_{4}$ emission and soil WFPS, $\mathrm{NH}_{4}{ }^{+}$content.

\begin{tabular}{cccc}
\hline \multicolumn{2}{c}{ The Regression } & \multicolumn{1}{c}{ Equation } & $\mathbf{R}^{2}$ \\
\cline { 1 - 2 } Y-CH \\
\hline
\end{tabular}

* indicates that $p<0.05$ according to T-TEST test; ${ }^{* *}$ indicates that $p<0.01$ according to T-TEST test. 

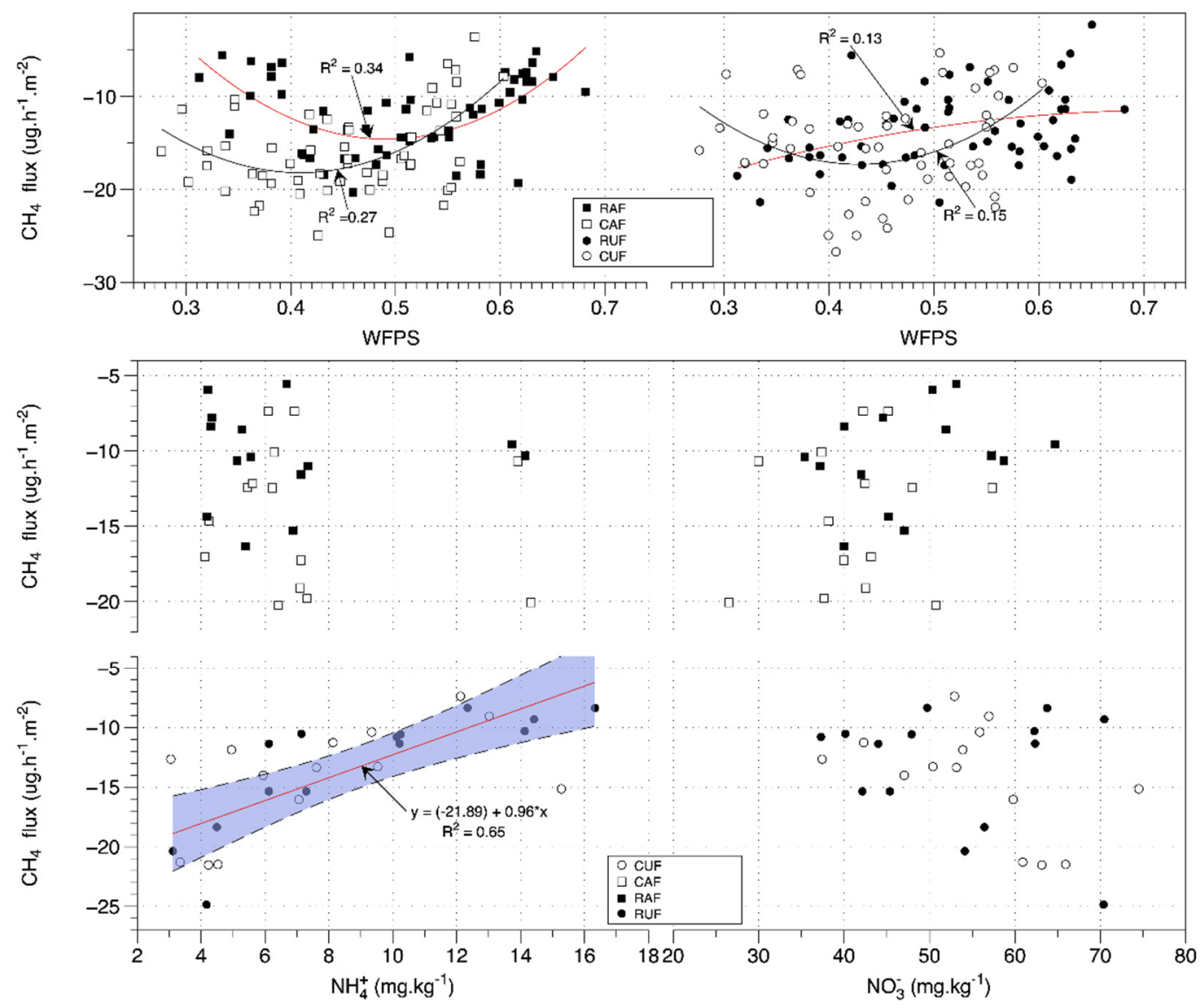

Figure 4. The regression between soil $\mathrm{CH}_{4}$ emission and WFPS, $\mathrm{NH}_{4}{ }^{+}$and $\mathrm{NO}_{3}{ }^{-}$. The shaded area is $95 \%$ confidence interval.

\subsection{Photosynthesis}

As shown in Figure 5, photosynthesis from 2014 to 2015 had similar varieties among all treatments; photosynthesis first increased and then decreased. There is a strong correlation between photosynthesis and temperature, the highest value appeared between 12:00 and 15:00, and the average value in the summer-maize period was higher than in the winterwheat period. The highest value appeared in August during the summer-maize period, white-wheat kept it steady among all treatments. As shown in Table 5, there was no significant difference $(p>0.05)$ between RW and CW, and photosynthesis in UF was higher than AF during the whole period.

Table 5. Cumulative carbon balance calculation from 2014 to 2015.

\begin{tabular}{ccccc}
\hline Treatment & $\begin{array}{c}\mathbf{C O}_{\mathbf{2}} \text { Emission } \\
\mathbf{t . h m}^{-2}\end{array}$ & $\begin{array}{c}\mathbf{C H}_{\mathbf{4}} \text { Emission } \\
\mathbf{t . h m ^ { - 2 }}\end{array}$ & $\begin{array}{c}\text { Photosynthesis } \\
\mathbf{t . h m}^{-\mathbf{2}}\end{array}$ & $\begin{array}{c}\text { Carbon Balance } \\
\text { t.hm }^{-2}\end{array}$ \\
\hline $\mathrm{RAF}$ & $64.41 \mathrm{a}$ & $-0.31 \mathrm{a}$ & $119.00 \mathrm{a}$ & $-54.90 \mathrm{a}$ \\
$\mathrm{RUF}$ & $66.61 \mathrm{a}$ & $-0.33 \mathrm{a}$ & $108.39 \mathrm{a}$ & $-42.11 \mathrm{a}$ \\
$\mathrm{CAF}$ & $61.64 \mathrm{a}$ & $-0.37 \mathrm{~b}$ & $115.80 \mathrm{a}$ & $-54.53 \mathrm{a}$ \\
$\mathrm{CUF}$ & $62.51 \mathrm{a}$ & $-0.36 \mathrm{~b}$ & $112.11 \mathrm{a}$ & $-49.96 \mathrm{a}$ \\
\hline
\end{tabular}

$\mathrm{CO}_{2}$ emission from 2014 to 2015 was listed on Table 4 refer to [22]; $\mathrm{CO}_{2}$ emission and $\mathrm{CH}_{4}$ emission is accumulative gas emission from 2014 to 2015. photosynthesis is average photosynthesis multiply time. Means followed by the same letter within a column are not significantly different according to t-test $(p<0.05)$. 

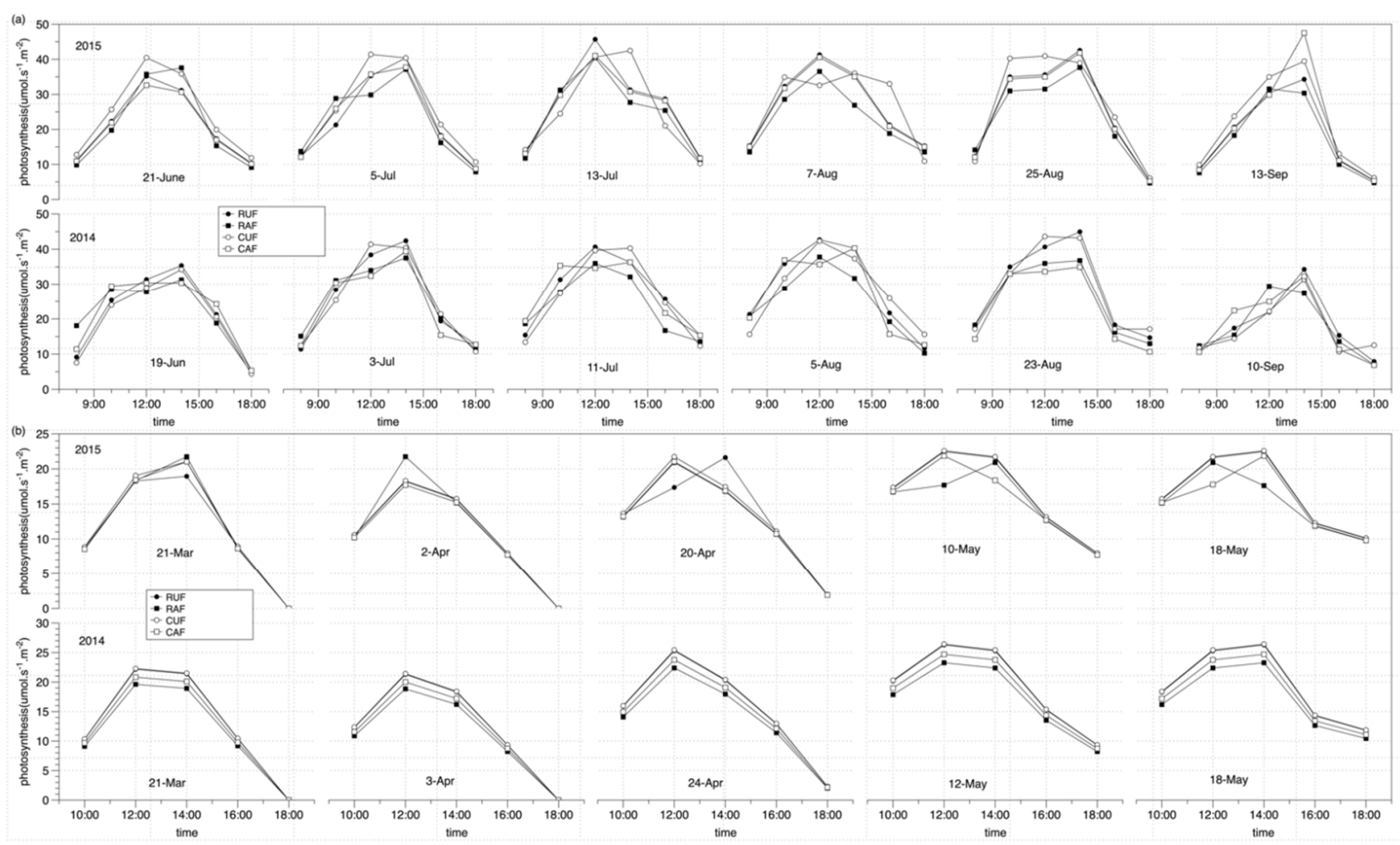

Figure 5. (a) The varieties of photosynthesis during the summer-maize period from 2014 to 2015; (b) The varieties of photosynthesis during the winter-wheat period from 2014 to 2015.

\subsection{The Effect of RW on Soil Carbon Balance}

$\mathrm{CH}_{4}$ uptake in dryland and plant photosynthesis were necessary parts of carbon sink. As shown in Table 5, the paper has demonstrated that RW can significantly decrease soil $\mathrm{CH}_{4}$ emission and not affect plant photosynthesis. Although RW could increase the $\mathrm{CO}_{2}$ emission in comparison with CW, RW could not impact carbon balance during the whole growth period in 2014 and 2015. Facing the field carbon balance, fertilization and field management were the key factors to determine the difference. By contrast, reclaimed water could effectively increase $\mathrm{CO}_{2}$ emission and decrease soil $\mathrm{CH}_{4}$ uptake, but it had no effect on carbon exchange between farmland and atmosphere.

\subsection{The Effect of RW on Soil Particle Size}

As shown in Figure 6, the distribution of soil particles was mainly attributed to the quality of irrigation water. Urea and slow-released fertilizer had no significant $(p>0.05)$ effect on the distribution. The soil particle size of RW was significantly $(p<0.05)$ larger than that of CW between 10-100 um. When soil particle size is greater than $10 \mathrm{um}$, the distribution in CW was significantly $(p<0.05)$ higher than RW. When soil particle size was less than $1 \mathrm{um}$, there was no significant difference between RW and CW from 2014 to 2015. 


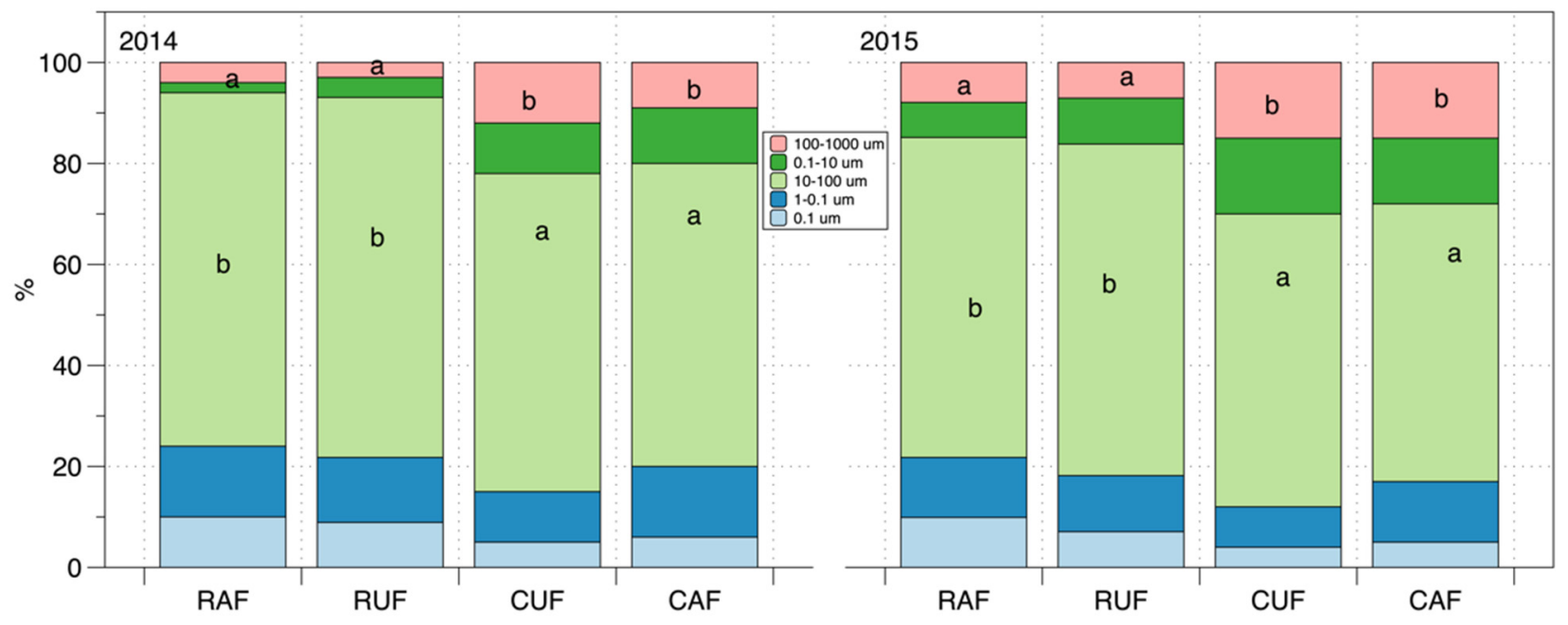

Figure 6. The distribution of particle size among all treatment in 2014 and 2015. Means followed by the same letter within a particle size range are not significantly different according to t-test $(p<0.05)$.

\section{Discussion}

In this paper it is demonstrated that methane is absorbed and its uptake has a strong relationship with WFPS. Other studies also considered that WFPS is an important factor which impacts $\mathrm{CH}_{4}$ uptake [25]. This could largely be attributed to the oxygen content in soil; the production of soil $\mathrm{CH}_{4}$ is driven by soil microorganism, methane oxidizing bacteria [26]. Some researchers showed that methane oxidizing bacterial reproduction could be provided by soil nutrients [27] or a good oxygen environment [28,29]. Although, in this study, reclaimed water could significantly decrease methane uptake from soil (Table 3), there was no difference between reclaimed water and clean water in soil nitrogen, $\mathrm{pH}$, and other factors (Figure 1). Therefore, RW might affect the distribution of soil particle size to impact soil aeration as that is the main factor affecting soil methane emission. Macroaggregate stability decreased for reclaimed water in our study (Figure 5) and soil organic carbon and soil nitrogen (Table 2). Some studies showed that a lower soil gas diffusivity and a higher mineral $\mathrm{N}$ content in soil could significantly decrease $\mathrm{CH}_{4}$ uptake [30]. Some researchers considered that reclaimed water irrigation could cause soil hardening and the soil structure quality could decrease with increasing sewage irrigation years [31,32]. Our results illustrated that RW had a better soil aeration in comparison with $\mathrm{CW}$, and soil aeration in RW could be easily impacted by soil WFPS. As shown in Table 3, the correlation $\mathrm{R}^{2}$ in RW was higher than CW. DZ et al. [33] also consider that reclaimed water irrigation could decrease soil water holding capacity and increase soil penetration resistance.

However, soil respiration is also necessary to impact $\mathrm{CH}_{4}$ uptake. The increasing soil respiration could effectively decrease $\mathrm{CH}_{4}$ emission from soil [34]. Liang et al. [35] showed that reclaimed water could improve soil respiration. Therefore, reclaimed water decreases $\mathrm{CH}_{4}$ uptake. It also explains the difference between UF and $\mathrm{AF}$ in $\mathrm{CH}_{4}$ uptake. Soil microbial activity could be affected by fertilizer type [36] and it could impact the activity of aerobic methanotrophs. As shown in Table 3, the $\mathrm{R}^{2}$ in AF was higher UF in addition to the effect of fertilization. The difference between them is attributed to the fertilizer method, urea could raise significantly soil respiration during the 3-5 days after fertilization $[37,38]$, it could accelerate the formation of tiny anaerobic areas in soil porosity in comparison with $\mathrm{AF}$ treatment.

RW as an alternative water source could effectively impact soil properties, increase soil $\mathrm{NO}_{3}{ }^{-}$content [39], reduce soil $\mathrm{pH}$, increase SOC [40] and EC. In this study, the carbon balance was calculated, and it was demonstrated that there is no significant $(p>0.05)$ difference between RW and CW. The variety of SOC increased only with the increase in irrigation and fertilization years (Table 1). However, the effect of reclaimed water irrigation on wheat and maize photosynthesis had no significant difference with clean water 
irrigation, as shown in Figure 4. Photosynthesis could be influenced by yield, illumination, soil microelement, etc. Most studies showed that reclaimed water could not significantly impact the yield [41]. Soil nitrogen, potassium, and magnesium play an important role in plant photosynthesis [42]. In our experiment, it is difficult to reflect on the effect of reclaimed water on crop photosynthesis because the amount of nitrogen applied is much greater than that in reclaimed water. In terms of carbon emission, RW could significantly improve soil respiration by increasing the abundance of microorganisms [43,44]. However, $\mathrm{CO}_{2}$ emission not only includes microorganism activity, but also crop root respiration. Irrigation, fertilizer, and air environment play an important role in crop root respiration [45] and these are similar among all treatments.

\section{Conclusions}

Quadratic correlation $(p<0.05)$ between methane flux and WFPS was found in this study, and the level of $40 \% \sim 50 \%$ WFPS had an advantage on methane oxidation. Irrigation, water quantity, and water quality are important factors in $\mathrm{CH}_{4}$ uptake on dryland, although they did not significantly impact crop photosynthesis. In addition, long term irrigation with reclaimed water can significantly decrease macroaggregate stability to decrease $\mathrm{CH}_{4}$ uptake $11.76 \% \sim 27.27 \%$. The application of urea enhanced $\mathrm{CO}_{2}$ emission and decreased $\mathrm{CH}_{4}$ uptake in comparison with the application of slow-release fertilizer, this is likely due to high levels of ammonium. Overall, slow-release fertilizer is recommended in this study in order to favorably control carbon gas emissions and to effectively increase carbon sequestration under reclaimed water irrigated agriculture.

Author Contributions: Y.C. and P.Y. designed the experiments; Y.C. and N.M. conducted the experiments.; N.M and Q.Z. contributed materials.; Y.C. and Q.Z. analyzed the data and wrote the paper.; S.R. revised the paper. All authors have read and agreed to the published version of the manuscript.

Funding: This research was funded by the National Key Research and Development Project of China, grant number (No. 2019YFC0408703).

Institutional Review Board Statement: Not applicable.

Informed Consent Statement: Not applicable.

Data Availability Statement: The data presented in this study are available on request from the corresponding author. The data are not publicly available due to the project is not finished.

Conflicts of Interest: The authors declare no conflict of interest.

\section{References}

1. Dunfield, P.F.; Yuryev, A.; Senin, P.; Smirnova, A.V.; Stott, M.B.; Hou, S.; Ly, B.; Saw, J.H.; Zhou, Z.; Yan, R. Methane Oxidation by an Extremely Acidophilic Bacterium of the Phylum Verrucomicrobia. Nature 2007, 450, 879-882. [CrossRef]

2. IPCC, Climate Change. The Physical Science Basis. Contribution of Working Group I to the Fourth Assessment Report of the Intergovernmental Panel on Climate Change; Solomon, S., Ed.; Cambridge University Press: Cambridge, UK, 2007.

3. Lashof, D.A.; Ahuja, D.R. Relative contributions of greenhouse gas emissions to global warming. Nature 1990, 334, 529-531. [CrossRef]

4. Jain, A.K.; Briegleb, B.P.; Minschwaner, K.; Wuebbles, D.J. Radiative forcing and global warming potentials of 39 greenhouse gases. J. Geophys. Res. 2000, 105, 20773-20790. [CrossRef]

5. Knief, C.; Lipski, A.; Dunfield, P.F. Diversity and Activity of Methanotrophic Bacteria in Different Upland Soils. Appl. Environ. Microbiol. 2003, 69, 6703-6714. [CrossRef] [PubMed]

6. Stiles, W.; Rowe, E.C.; Dennis, P. Nitrogen and Phosphorus Enrichment Effects on $\mathrm{CO}_{2}$ and Methane Fluxes from an Upland Ecosystem. Sci. Total Environ. 2018, 618, 1199. [CrossRef]

7. Zheng, Y.; Wei, Y.; Xiang, S.; Wang, S.P.; Guo, L.D. Methanotrophic Community Structure and Activity under Warming and Grazing of Alpine Meadow on the Tibetan Plateau. Appl. Microbiol. Biotechnol. 2012, 93, 2193-2203. [CrossRef] [PubMed]

8. Dobbie, K.E.; Smith, K.A. Comparison of $\mathrm{CH}_{4}$ Oxidation Rates in Woodland, Arable and Set aside Soils. Soil Biol. Biochem. 1996, 28, 1357-1365. [CrossRef]

9. Li, Z.; Zhang, R.; Wang, X.; Chen, F.; Lai, D.; Tian, C. Effects of Plastic Film Mulching with Drip Irrigation on $\mathrm{N}_{2} \mathrm{O}$ and $\mathrm{CH}_{4}$ Emissions from Cotton Fields in Arid Land. J. Agric. Sci. 2014, 152, 534-542. [CrossRef] 
10. Zhang, X.; Shan, Y.; Li, Y.; Zhuang, H.; Li, C.; Liu, C. Comparison of Greenhouse Gas Emissions from Rice Paddy Fields under Different Nitrogen Fertilization Loads in Chongming Island, Eastern China. Sci. Total Environ. 2014, 472, 381-388. [CrossRef]

11. Mo, X.; Liu, S.; Lin, Z.; Guo, R. Regional Crop Yield, Water Consumption and Water Use Efficiency and Their Responses to Climate Change in the North China Plain. Agric. Ecosyst. Environ. 2009, 134, 67-78. [CrossRef]

12. Wang, J.; Wang, G.; Wanyan, H. Treated Wastewater Irrigation Effect on Soil, Crop and Environment: Wastewater Recycling in the Loess Area of China. J. Environ. Sci. 2007, 19, 1093-1099. [CrossRef]

13. Hamilton, A.J.; Stagnitti, F.; Xiong, X.; Kreidl, S.L.; Benke, K.K.; Maher, P. Wastewater Irrigation: The State of Play. Vadose Zone J. 2007, 6, 823-840. [CrossRef]

14. Antolín, M.C.; Muro, I.; Sánchez-Díaz, M. Application of Sewage Sludge Improves Growth, Photosynthesis and Antioxidant Activities of Nodulated Alfalfa Plants under Drought Conditions. Environ. Exp. Bot. 2010, 68, 75-82. [CrossRef]

15. Ashrafi, N.; Gheysari, M.; Maleki, A.; Nikbakht, A. Effect of Irrigation with Reclaimed Water on Fruit Characteristics and Photosynthesis of Olive Trees under Two Irrigation Systems. Majallah-i $\bar{a} b$ va Khāk 2016. [CrossRef]

16. Li, M.; Xue, L.; Zhou, B.; Duan, J.; He, Z.; Wang, X.; Xu, X.; Yang, L. Effects of Domestic Sewage from Different Sources on Greenhouse Gas Emission and Related Microorganisms in Straw-Returning Paddy Fields. Sci. Total Environ. 2020, $718,137407$. [CrossRef]

17. Zou, J.; Liu, S.; Qin, Y.; Pan, G.; Zhu, D. Sewage Irrigation Increased Methane and Nitrous Oxide Emissions from Rice Paddies in Southeast China. Agric. Ecosyst. Environ. 2009, 129, 516-522. [CrossRef]

18. Ibekwe, A.M.; Gonzalez-Rubio, A.; Suarez, D.L. Impact of Treated Wastewater for Irrigation on Soil Microbial Communities. Sci. Total Environ. 2017, 8. [CrossRef] [PubMed]

19. Qian, Y.L.; Mecham, B. Long-Term Effects of Recycled Wastewater Irrigation on Soil Chemical Properties on Golf Course Fairways. Agron. J. 2005, 97, 717-721. [CrossRef]

20. Chi, Y.; Yang, P.; Ren, S.; Ma, N.; Yang, J.; Xu, Y. Effects of Fertilizer Types and Water Quality on Carbon Dioxide Emissions from Soil in Wheat-Maize Rotations. Sci. Total Environ. 2020, 698, 134010. [CrossRef]

21. Wang, Y.Y.; Hu, C.S.; Ming, H.; Zhang, Y.M.; Li, X.X.; Dong, W.X.; Oenema, O. Concentration Profiles of $\mathrm{CH}_{4}, \mathrm{CO}_{2}$ and $\mathrm{N}_{2} \mathrm{O}$ in Soils of a Wheat-Maize Rotation Ecosystem in North China Plain, Measured Weekly over a Whole Year. Agric. Ecosyst. Environ. 2013, 164, 260-272. [CrossRef]

22. Hashimoto, S.; Morishita, T.; Sakata, T.; Ishizuka, S.; Kaneko, S.; Takahashi, M. Simple Models for Soil $\mathrm{CO}_{2}, \mathrm{CH}_{4}$ and $\mathrm{N}_{2} \mathrm{O}$ Fluxes Calibrated Using a Bayesian Approach and Multi-Site Data. Ecol. Model. 2011, 222, 1283-1292. [CrossRef]

23. Konda, R.; Ohta, S.; Ishizuka, S.; Arai, S.; Ansori, S.; Tanaka, N.; Hardjono, A. Spatial Structures of $\mathrm{N}_{2} \mathrm{O}, \mathrm{CO}_{2}$ and $\mathrm{CH}_{4} \mathrm{Fluxes}$ from Acacia Mangium Plantation Soils during a Relatively Dry Season in Indonesia. Soil Biol. Biochem. 2008, 40, 3021-3030. [CrossRef]

24. Wei, C.; Li, F.; Yang, P.; Ren, S.; Wang, S.; Wang, Y.; Xu, Z.; Xu, Y.; Wei, R.; Zhang, Y. Effects of Irrigation Water Salinity on Soil Properties, $\mathrm{N}_{2} \mathrm{O}$ Emission and Yield of Spring Maize under Mulched Drip Irrigation. Water 2019, 11, 1548. [CrossRef]

25. Meng, C.; Wang, F.; Yang, K.; Shock, C.C.; Engel, B.A.; Zhang, Y.; Tao, L.; Gu, X. Small Wetted Proportion of Drip Irrigation and Non-Mulched Treatment with Manure Application Enhanced Methane Uptake in Upland Field. Agric. Forest Meteorol. $2019,281$. [CrossRef]

26. Orphan, V.J.; Hinrichs, K.U.; Ussler, W.; Paull, C.K.; Taylor, L.T.; Sylva, S.P.; Hayes, J.M.; Delong, E.F. Comparative Analysis of Methane-Oxidizing Archaea and Sulfate-Reducing Bacteria in Anoxic Marine Sediments. Appl. Environ. Microbiol. 2001, 67, 1922-1934. [CrossRef]

27. Bodelier, P.; Roslev, P.; Henckel, T.; Frenzel, P. Stimulation by Ammonium-Based Fertilizers of Methane Oxidation in Soil around Rice Roots. Nature 2000, 403, 421-424. [CrossRef] [PubMed]

28. Meyer, W.S.; Barrs, H.D.; Smith, R.C.G.; White, N.S.; Heritage, A.D.; Short, D.L. Short Effect of Irrigation on Soil Oxygen Status and Root and Shoot Growth of Wheat in a Clay Soil. Crop Pasture Sci. 1985, 36, 171-185. [CrossRef]

29. Bonachela, S.; Acuna, R.A.; Casas, J. Environmental Factors and Management Practices Controlling Oxygen Dynamics in Agricultural Irrigation Ponds in a Semiarid Mediterranean Region: Implications for Pond Agricultural Functions. Water Res. 2007, 41, 1225-1234. [CrossRef] [PubMed]

30. Yonemura, S.; Nouchi, I.; Nishimura, S.; Sakurai, G.; Togami, K.; Yagi, K. Soil Respiration, $\mathrm{N}_{2} \mathrm{O}$ and $\mathrm{CH}_{4}$ Emissions from an Andisol under Conventional-Tillage and No-Tillage Cultivation for 4 Years. Biol. Fertil. Soils 2014, 50, 63-74. [CrossRef]

31. Levy, G.J.; Rosenthal, A.; Tarchitzky, J.; Shainberg, I.; Chen, Y. Soil Hydraulic Conductivity Changes Caused by Irrigation with Reclaimed Waste Water. J. Environ. Qual. 1999, 28, 1658-1664. [CrossRef]

32. Lv, Y.; Guan, X.Y.; Ruan, B.Q.; Wang, Y.W. Multifractal Characteristics of Soil Particle Size Distribution under Sewage Irrigation in Different Irrigation Years. Appl. Mech. Mater. 2015, 700, 205-210. [CrossRef]

33. Dz, A.; Rb, B.; Sm, A.; Mp, A.; Gd, B. Influence of Reclaimed Water Irrigation in Soil Physical Properties of Urban Parks: A Case Study in Madrid (Spain). Catena 2019, 180, 333-340.

34. Bridgham, S.D.; Richardson, C.J. Mechanisms Controlling Soil Respiration $\left(\mathrm{CO}_{2}\right.$ and $\left.\mathrm{CH}_{4}\right)$ in Southern Peatlands. Soil Biol. Biochem. 1992, 24, 1089-1099. [CrossRef]

35. Liang, P.; Jingan, X.; Liying, S. Effects of Reclaimed Water Irrigation on the Soil Characteristics and Microbial Populations of Plant Rhizosphere. Environ. Sci. Pollut. R 2021. [CrossRef] [PubMed] 
36. Iqbal, J.; Hu, R.; Lin, S.; Hatano, R.; Feng, M.; Lu, L.; Ahamadou, B.; Du, L. CO 2 Emission in a Subtropical Red Paddy Soil (Ultisol) as Affected by Straw and N-Fertilizer Applications: A Case Study in Southern China. Agric. Ecosyst. Environ. 2009, 131, $292-302$. [CrossRef]

37. Ward, D.; Kirkman, K.; Hagenah, N.; Tsvuura, Z. Soil Respiration Declines with Increasing Nitrogen Fertilization and Is Not Related to Productivity in Long-Term Grassland Experiments. Soil Biol. Biochem. 2017, 115, 415-422. [CrossRef]

38. Ding, W.; Meng, L.; Yin, Y.; Cai, Z.; Zheng, X. $\mathrm{CO}_{2}$ Emission in an Intensively Cultivated Loam as Affected by Long-Term Application of Organic Manure and Nitrogen Fertilizer. Soil Biol. Biochem. 2007, 39, 669-679. [CrossRef]

39. Lu, S.; Zhang, X.; Liang, P. Influence of Drip Irrigation by Reclaimed Water on the Dynamic Change of the Nitrogen Element in Soil and Tomato Yield and Quality. J. Clean. Prod. 2016, 139, 561-566. [CrossRef]

40. Chen, W.; Lu, S.; Pan, N.; Wang, Y.; Wu, L. Impact of Reclaimed Water Irrigation on Soil Health in Urban Green Areas. Chemosphere 2015, 119, 654-661. [CrossRef]

41. Da Fonseca, A.F.; Melfi, A.J.; Montes, C.R. Maize Growth and Changes in Soil Fertility After Irrigation with Treated Sewage Effluent. I. Plant Dry Matter Yield and Soil Nitrogen and Phosphorus Availability. Commun. Soil Sci. Plant Anal. 2005, 36, 1965-1981. [CrossRef]

42. Plénet, D.; Mollier, A.; Pellerin, S. Growth Analysis of Maize Field Crops under Phosphorus Deficiency. II. Radiation-Use Efficiency, Biomass Accumulation and Yield Components. Plant Soil 2000, 224, 259-272. [CrossRef]

43. Wu, S.; Li, H.; Zhou, X.; Liang, P.; Zhang, X.; Jiang, Y.; Huang, X. A Novel Pilot-Scale Stacked Microbial Fuel Cell for Efficient Electricity Generation and Wastewater Treatment. Water Res. 2016, 98, 396-403. [CrossRef] [PubMed]

44. Saha, J.K.; Panwar, N.; Srivastava, A.; Biswas, A.K.; Kundu, S.; Rao, A.S. Chemical, Biochemical, and Biological Impact of Untreated Domestic Sewage Water Use on Vertisol and Its Consequences on Wheat (Triticum Aestivum) Productivity. Environ. Monit. Assess. 2010, 161, 403-412. [CrossRef] [PubMed]

45. Cabangon, R.J.; Tuong, T.P.; Castillo, E.G.; Bao, L.X.; Lu, G.; Wang, G.; Cui, Y.; Bouman, B.A.M.; Li, Y.; Chen, C.; et al. Effect of Irrigation Method and N-Fertilizer Management on Rice Yield, Water Productivity and Nutrient-Use Efficiencies in Typical Lowland Rice Conditions in China. Paddy Water Environ. 2004, 2, 195-206. [CrossRef] 